\title{
Recombinant DNA research: private actions raise public eyebrows
}

Rival scientific groups, often working towards common goals, share a close network of financial supporters.

\section{David Dickson reports}

LAST Thursday, the US Court of Customs and Patent Appeals confirmed its earlier decision that patent applications could be granted on two separate microorganisms, the one developed by scientists with General Electric, the other by Upjohn Co.

For the second time in 18 months, the court reversed a decision by the Patents and Trademarks Office refusing the patent applications on the grounds that the microorganisms were products of nature. The re-evaluation was made necessary by a Supreme Court ruling last June that the Appeals Court should reconsider its verdict in the light of a decision that a particular computer program was not patentable.

Three of the five Appeals Court judges, in repeating their previous position, said that they failed to see any connection between the computer program and the microorganism cases. And it could therefore be some time before a final verdict - the outcome of which is being awaited before patent applications are considered for a growing list of recombinant DNA inventions-is reached, since the Patent Office may well choose to take the case back to the Supreme Court for final clarification.

Whatever the outcome, however. growing confidence in the US business community that the development of recombinant DNA technologies promises large profits has led to a steady flow of venture capital to support research. Noone has yet made very much money, but high commercial expectations have helped raise the value (on paper) of the five small private companies most deeply involved to a figure estimated at more than $\$ 150$ million.

In the rush for commercial pay-offs, however, some of the tactics used are beginning to raise various concerns on Capitol Hill, such as whether private industry's voluntary compliance with the National Institutes of Health's guidelines provides an adequate basis for ensuring the same degree of safety in private industry as the guidelines currently require in university laboratories.

Some of the issues are:

- Private corporations have already financed research by US scientists in various European laboratories to carry out experiments for which the facilities required by the guidelines at the time were not available in the US.
- A major pharmaceutical company is providing backing for two of the leading three teams investigating the possible production of human insulin by bacteria (and has tried--unsuccessfully - to gain a license to develop the results of the third team)

- A transnational recombinant DNA company has been set up by a Canadian multinational company with a group of leading scientists from Europe and the US. Capital for the company has been raised on both sides of the Atlantic, and the arrangement permits experiments to be located in the country offering the most acceptable environment for the research.

- As reported in Nature last week, at least one US company is already planning to conduct experiments involving more than ten litres of culture without receiving prior formal approval from the NIH, as the current guidelines require of federally-sponsored research.

The rapid growth of the small research companies, representing a direct marriage between university research workers and finance raised on the venture capital market, bears many similarities to the growth of the electronics industry ten years ago. Although most of the large pharmaceutical companies are building up their in-house capability to do such research, in most cases they have been less aggressive and slower to accept the commercial potential of the new technology than outside investors who are more prepared to take speculative risks.

In addition, rather than selling the licence to develop patents arising from their research direct to the major

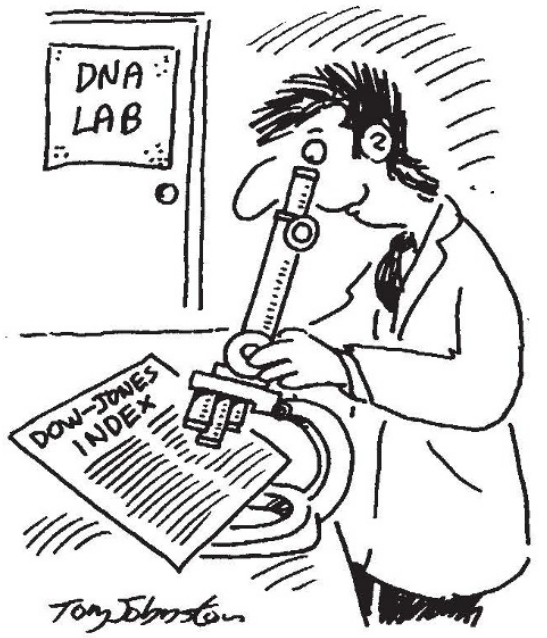

companies, a number of scientists have preferred to set up their own commercial ventures, often using the money they have raised to licence the patents from work they have carried out on federally funded grants. "A fact of life is that the vast majority of talent in the field is in the universities at the present time," says Professor David Jackson of the University of Michigan.

Five relatively small companies currently occupy the centre of the stage. These are:

- Cetus Corporation, set up in Berkeley, California in 1971 on an initial capital of $\$ 5$ million, and currently carrying out research on a contract basis for industry in a number of areas, including biomedical, chemical, food and agricultural technologies. Cetus has opened a P3 facility, and its current value on paper is estimated by president Dr Peter Farley as around $\$ 65$ million. Almost half of this stock is owned by Standard Oil and National Distillers Company.

- Genentech, Cetus' rival across the bay in San Francisco, which claims to be "the leading company in the application of recombinant DNA techniques to problems in human health care". Set up in 1976 by Robert Swanson and Dr Herbert Boyer, Genetech is also interested in a wide range of applications, but has gained most publicity for its work on somatostatin and insulin.

- Biogen, a company incorporated in Luxembourg, which was set up last year by $\mathrm{Mr}$ Dan Adams, then head of the venture capital division of International Nickel. Biogen has nine scientist co-founders from both sides of the Atlantic, and has so far concentrated mainly on working towards pharmaceutical products such as insulin, interferon and a possible hepatitis vaccine. Adams estimates the current value to be about $\$ 50$ million and Biogen is currently constructing laboratories in Switzerland to P3 containment levels.

- Genex, established in 1977 by Dr Jackson of Michigan and two others. It is concentrating on industrial processes involved in, for example, the food and chemical industries. Genex plans to open a laboratory in Rockville, Maryland in the near future, and to announce a major deal with "one of the fortune 500 companies", within the next four weeks according to president Dr Leslie Glick.

- Bethesda Research Laboratories, set up three years ago and already a major 
supplier of restriction enzymes. It started moving into recombinant DNA research last summer, and has opened a P2 facility also in Rockville (rapidly becoming the "route 128" of molecular biology, largely because of its proximity to NIH).

In addition, collaborative research, in Waltham, Massachusetts, which already supplies materials such as synthetic genes required for research to a number of the companies listed above, is now contemplating entering the field directly, according to its president, Dr Orrie Friedman.

At the scientific level, research groups supported by the various companies are frequently exploring different paths towards the same goals, characterised by the fierce-though usually friendly-rivalry common to all fields of science. Some of these goals include the production by bacterial means of insulin, interferon, growth hormone, and various industrial enzymes.

At the financial level, however, the situation is slightly different. Apart from Bethesda Research Labs, which is financed by a private family trust, the other four companies share some common financial backers in what one participant acknowledges to be a "somewhat incestuous" relationship.

For example, Kleiner and Perkins, an established West coast venture capital firm which supplied the backing for electronics companies such as Fairchild Industries, has provided substantial support for both Cetus and Genentech, although Dr Farley of Cetus says that the standard oil support now puts the company apart from the other three. Similarly, New Jersey, which receives its own funds from companies such as Aetna Life Insurance, Emerson Electric, and the Monsanto Chemical Company, has a stake in Genentech, and last year provided a substantial amount of capital to Genex. Mr Gerald Large, president of Innoven, is now a director of Genex.

Perhaps the most extensive involvement has been that of International Nickel, (INCO), a Canadian based mineral company, which set up a venture capital division operating from New York in 1975 to support "worthwhile entrepreneurial investment opportunities in Canada, the US and Europe." Soon after it began operations, the then head of the division, Mr Dan Adams, selected recombinant DNA technology as a fruitful field for investment. "I felt that this was the most exciting field of technology for investment for the immediate future," he said last week.

In line with this conviction, INCO bought a small amount of stock in Cetus in 1976 valued at about $\$ 500,000$ and subsequently in 1977 bought a larger, $10 \%$ share in Genentech. Then in 1978, with advice from Genentech(which is now demanding a share in the equity in return), and a scientific board brought together by Dr Walter Philip Sharp of MIT, INCO set up a Gilbert of Harvard University and Dr new company, Biogen, with Adams as president (Adams has since left both INCO and Biogen, but is looking for new areas to start a similar venture).

INCO was incorporated in Luxembourg, "which has some attractive tax advantages", according to Adams, and sponsors research in the laboratories of a number of members of its scientific boards, such as that of Dr Charles Weissman, of the Institute for Molecular Biology at the University of Zurich.

Financing provided largely by INCO through Biogen has already allowed Gilbert to carry out experiments into the production of human insulin at the Microbiological Research Establishment at Porton Down in the UK, since at the time the P4 containment facilities required by the NIH guidelines were not available in the US.

Of the major pharmaceutical companies, Eli Lilley has been the most aggressive in pursuing potentially valuable research results (as well as the most vocal critic of attempts to legislate basic research in the private sector). The company currently controls $80 \%$ of the $\$ 140$ million domestic insulin market, and is keen to maintain this position.

Last Autumn. Eli Lilley entered an agreement with Genentech clinched soon after scientists in the latter company announced they had produced human insulin from bacteria (although the insulin produced in this way has yet to be shown to be biologically active) under which the two companies will carry out a joint long-term manufacturing and marketing programme.

In addition, Eli Lilley has entered a separate agreement with Dr Howard Goodman and Dr Bill Rutter of the University of San Francisco in the Department of Biochemistry and Biophysics. The pharmaceutical company has provided over $\$ 250,000$ to support the laboratory's research into the production of human insulin, money which last year allowed research workers from the laboratory to carry out experiments in France which could not be done in the US.

In return for providing financial support, the company expects first refusal on the license to develop any patentable results which arise from the research.

In addition to the above two agreements, Eli Lilley recently bid unsuccessfully to purchase from Harvard University the rights to develop the patent filed by Gilbert for research developed in connection with other research teams at Harvard (the British drug company Boots, also expressed interest in licensing the patent but Harvard decided that the patent should go to Biogen).

Within this complex of financial and corporate interests, those involved are taking pains to emphasise that all research-at least that which is carried out in the US, and at least with respect to the technical aspects of containment levels - is conducted in accordance with the criteria in the NIH guidelines.

For research outside the US, however, it is generally accepted-even by NIH itself - that these guidelines need not apply, strictly but that the research should be done in compliance with local requirements (making countries with relatively low requirements attractive).

However, evidence that companies are already more than willing to move abroad to carry out research that cannot be done in the US is beginning to worry US lawmakers, which have so far held back from legislating over the private sector. "This is certainly something we are keeping a close eye on" a staff aide to Senator Adlai Stevenson's science subcommittee said last week.

In return, companies are worried about a proposal by the Food and Drug Administration to introduce regulations that would require all research leading to products for which licenses are applied to have been conducted under the NIH guidelines. They are suggesting that, if the work is carried out abroad, the compliance should be with local guidelines. "It would be silly for FDA or NIH to try to police the world" said Adams.

Meanwhile other critics of existing policy and of the NIH sponsored decision processes are concerned that without legislation explicitly covering the private sector, there will be no way of guaranteeing the safety of the procedures that this sector adopts. In the wake of last week's nuclear power incident at Harrisburg public credibility of claims of minimal danger is running olw (already scientists at Tufts University have demonstrated that a "disabled" E. Coli strain classified as EK2 is capable of surviving up to 90 hours in the human gut. far longer than was initially anticipated).

"The question remains who is going to control both the process and the products of this research," says Dr Susan Wright of the University of Michigan. "Given that great uncertainties still exist, and the fact that risk assessment experiments have not yielded uniformly negative results and have indicated some areas for renewed concern, it is important that Congress does all that it can to guarantee the safety of those involved. 